\title{
Konstruksi sosial pernikahan beda agama di kalangan Muslim Tionghoa di Probolinggo
}

\author{
M. Hasyim Syamhudi
}

IAIN Sunan Ampel Surabaya, DPK. LAI Nurul-Jadid Paiton Probolinggo

E-mail: basyimsyambudi@ymail.com

The reciprocal connection between religion and family life makes the topic of religious intermarriage of particular importance in the sociology of religion. This study was conducted to examine social phenomena of interreligious marriage which become popular among Moslems Chinese society in Probolinggo. The main purpose of this study will try to find, why Moslems Chinese society in Probolinggo perform interfaith marriage, which was all the long associated to be forbiden in both Islamic legal system and possitive common law of Indonesia. In this research the researcher has difficulties to get proper information about religious behavior, especially about interfaith marriage problems. To solve this problem, the researcher asked for help from the leader of Persatuan Imam Tauhid Indonesia (PITI) Probolinggo, Mr. Irem Grok Sing to get access to main informans. This qualitative research used Berger's theory of social reconstruction process to explain phenomena. Interreligious martiage as a social discordance in Probolinggo Chinese Moslem community was predicted will expand faster. So there was need some dialogue between religious ideal concepts. In Islamic law, this phenomena can be understood as an actualization of the rabmatan li al-alamin mission.

Keywords: Social construction; Muslim-non-Muslim marriage; Chinese Muslim; Islamic ideals

\section{Pendahuluan}

Pemikahan beda agama di kalangan etnis Tionghoa, mulai banyak digemari akhir-akhir ini, khususnya yang telah memeluk Islam. Hal tersebut dijelaskan oleh Iskandar Syam, petugas pencatat nikah di kantor Catatan sipil kabupaten Probolinggo. Dia menjelaskan bahwa pada tahun 2009 telah terjadi beberapa kali pernikahan beda agama seperti pernikahan yang diakukan oleh. Alfan Prasetio Hendrawan dari desa Karang Dampit Kecamatan Kraksaan 
yang beragama Kristen, dengan Ratih Wijayanti dari Surabaya yang beragama Islam. Pernikahan keduanya dicatat menurut pernikahan secara Kristen. Demikian juga pernikahan Tjoe Lian Khin (Mulyono) dari Situbondo yang beragama Budha, yang menikah dengan Indrawati dari Pajarakan Probolinggo yang beragama Kristen. Pada umumnya, pernikahan lintas agama ini dicatat menurut satu agama saja, sebab undang-undang Tahun 1974 Nomor 1 tidak mengenal pernikahan lintas agama.

Menariknya, fenomena serupa juga ditemukan di dalam lingkungan rumah tangga muslim Tionghoa yang tergabung dalam organisasi Pembina Iman Tauhid Islam (PITI) Probolinggo. Gede Vendana Wijaya misalnya, seorang pemuda keturunan Tionghoa beragama Islam, yang menikah dengan Lusiana, yang juga beretnis Tionghoa, beragama Katolik dan pernikahannya dilaksanakan secara Katolik. Gede Vendana Wijaya adalah putra dari H. Moh. Made Sindrajaya dan $\mathrm{Hj}$. Alfi Zahro yang dalam organisasi PITI Kabupaten Probolinggo dipercaya sebagai bendahara.

Di dalam rumah tangga H. Moh. Made Sindrajaya yang kesehariannya memimpin Rumah Sakit dan Apotik Sehat bersama isterinya di kota Kraksaan, berdiam juga adik isteri, Nunik yang beragama Kristen dengan suaminya Iwan'Santuso, laki-laki beretnis Tionghoa yang beragama Kristen Protestan. Namun demikian, relasi antar anggota keluarga di dalam rumah tangganya berjalan harmonis, tanpa harus mempersoalkan perbedaan keyakinan agama yang dianutnya. Pernikahan beda agama ternyata tidak hanya dilakukan oleh keluarga $\mathrm{H}$. Moh. Made Siridrajaya, tetapi juga dilaksanakan oleh pengurus (PITI) Probolinggo yang lain seperti, Liem Giok Sing (H. Moh. Ali Makki) selaku ketua, Tan Tjin Gan (H. Edi Santuso) selaku sekretaris, Tjan Tong Hin (H. Edi Saputra) selaku wakil ketua dan Poo Gwan Tek (H. Sutikno) selaku anggota.

Pada titik ini, satu fenomena yang menarik bagi peneliti adalah bahwa warga etnis Tionghoa yang tergabung dalam (PITI), ternyata tidak mempersoalkan kehadiran rumah tangga beda agama ini. Mereka juga mendukung serta menghadiri saat perhelatan perkawinan dilaksanakan, walaupun pernikahan beda agama masih menjadi sesuatu yang diperdebatkan keabsahannya dalam ranah hukum Islam. Sekilas, fakta ini memberikan pemahaman awal bahwa konstruksi sosial masyarakat muslim Tionghoa di Probolinggo, tidak memiliki keterkaitan dengan konstruksi teologis tentang pernikahan beda agama. Hanya saja, kesemuanya tentu memiliki 
faktor dan alasan, yang kesemuanya hendak diteliti dengan rumusan masalah yakni, bagaimana konstruksi sosial pernikahan beda agama di kalangan etnis Tionghoa Probolinggo dan bagaimana pula pemahaman mereka terhadap konstruksi teologis pernikahan beda agama dalam Islam.

\section{Pernikahan beda agama di kalangan etnis Tionghoa}

Pernikahan beda agama yang dilakukan oleh etnis Tionghoa Probolinggo merupakan konstruksi sosial dari hasil dialog keyakinan agama yang mereka anut dengan lingkungan masyarakat di mana mereka berada. Hal tersebut terjadi karena agama yang dikaitkan dengan hal-hal yang bersifat supranatural, sulit dipahami dan untuk memahaminya dilakukan berbagai bentuk ritual dalam sebuah tradisi keagamaan yang sering tidak tersambung dengan bigh madition dari agama itu sendiri (Geertz, 1983: 38).

Di dalam agama Kong $\mathrm{Hu} \mathrm{Cu}$ misalnya, ada tradisi menangis dan tidur di atas batu, padahal tradisi tersebut tidak pernah diajarkan dan tidak ada dalam ajaran Kong $\mathrm{Hu} \mathrm{Cu}$. Menurut, Tiong Hoa Hwee Koen (THHK) sebuah organisasi di kalangan etnis Tionghoa, seridaknya ada dua puluh lima macam adat istiadat agama Kong $\mathrm{Hu} \mathrm{Cu}$ yang mengalami pembaruan karena tidak ditemukan dalam bigh tradition dalam agama Kong $\mathrm{Hu} \mathrm{Cu}$ itu sendiri (Suryadinata, 2002: 157). Apa yang ditemukan oleh THHK merupakan hasil dari konstruksi sosial dari pengikut agama Kong $\mathrm{Hu} \mathrm{Cu}$ pada saat mereka bersosialisasi dengan warga dan masyarakat sekitar.

Tradisi atau adat istiadat tersebut, menurut Emile Durkheim disebut sebagai lambang kesakralan (agama, pen.) yang bersumber kepada apa yang dinyatakan berlaku oleh masyarakat secara keseluruhan bagi setiap anggotanya dan berfungsi sebagai mempertahankan dan memperkuat rasa solidaritas dan kewajiban sosial (Scharf, 2004: 73).

Dari pendekatan Durkheim ini dapat dipahami bahwa pernikahan beda agama di kalangan maslim Tionghoa Probolinggo, secara sosiologis tidak selalu disandarkan kepada bigh traditior dari suatu agama yang diyakini, tetapi bersumber dari konstruksi sosial mereka pada saat bersosialisasi dengan masyarakat sekitar, melaksanakan agamanya dalam upaya mempertahankan dan memperkuat rasa solidaritas dan kewajiban sosial di antara mereka. 
lithad, Jurnal Wacana Hukum Islam dan Kemanusiaan, Vol. 11, No. 2, Desember 2011: 127-143

Apa yang dilakukan Alfan Prasetio Hendrawan dari desa Karang Dampit Kecamatan Kraksaan Ptobolinggo yang beragama Kristen untuk melakukan pernikahan dengan Ratih Wijayanti dari Surabaya yang beragama Islam dan pernikahannya dicatat menurut pernikahan agama Kristen, tidak akan pernah ditemukan di dalam bigh tradition agama masing-masing baik Kristen maupun Islam. Demikian juga Tjoe Lian Khin (Mulyono) dari Situbondo yang beragama Budha dengan Indrawati dari Pajarakan Probolinggo yang beragama Kristen dan pernikahannya dicatat menurut pernikahan agama Budha, semuanya adalah fenomena sosial yang merupakan hasil dari dialog pelaksanaan agama yang diyakininya dengan lingkungan masyarakat sekitarnya.

Meskipun teori Durkheim dibangun dari hasil penelitiannya pada masyarakat Arunta di Australia tengah, namun teori tersebut dapat disamakan dengan tradisi pernikahan beda agama di Probolinggo dalam hal memperkuat dan mempertahankan solidaritas di antara sesama etnis Tionghoa dalam sebuah rumah tangga yang dibangunnya.

Kemudian jika Emile Durkheim melihat tradisi/lambang kesakralan sebagai fenomena sosial keagamaan dati prespektif hasil, maka tidak demikian Peter L. Berger yang justeru melihat fenomena sosial tersebut dari prespektif proses yang secara sosiologis merupakan kontruksi dari tahapan Eksternalisasi, Obyektivasi dan Internalisasi (Berger, 1991: 73).

Eksternalisasi, yang berarti proses pencurahan manusia sebagai individu ke dalam lingkungan masyarakat, dalam kaitannya dengan pernikahan beda agama di kalangan muslim Tiongho: Probolinggo, dapat dilihat dari penerimaan masyarakat itu sendiri yang sangat luar biasa terhadap keberadaan pernikahan beda agama, baik pada saat pelaksanaan maupun setelah rumah tangga yang dibangun berinteraksi di tengah-tengah kehidupan masyarakat dan menjadi bagian integral dari kehidupan masyarakat tersebut.

Dalam perjalanan sejarah kemanusiaan proses eksternalisasi sebagai konstruksi sosial, memang tidak selamanya menghasilkan sesuatu seperti yang diharapkan. Banyak di antaranya yang mengalami kegagalan karena adanya penolakan dari lingkungan masyarakatnya. Hal ini sangat tergantung kepada kesiapan masyarakat itu sendiri untuk menerima dan menyertai kemampuan individu dalam mempersiapkan visi dan misinya sebelum proses eksternalisasi dilakukan. Laksamana Moh. Cheng Ho termasuk yang berhasil ketika dia melakukan proses eksternalisasi, sementara utusan Khubilaikan, Meng K'i, termasuk yang mengalami kegagalan 


\section{ketika nuansa yang sama dilakukan.}

Proses eksternalisasi pernikahan beda agama di kalangan etnis Tionghoa Probolinggo meraih kesuksesan setelah melalui proses sosialisasi dengan masyarakat sekitar dan segala institusinya, seperti agama, budaya serta norma kehidupan yang berlaku di tengah-tengah kehidupan umat beragama yang mayoritas beragama Islam.

Jika proses eksternalisasi Peter L. Berger dijadikan pendekatan untuk memahami konstruksi sosial pernikahahan beda agama, maka hal tersebut dapat diilustrasikan sebagai berikut:

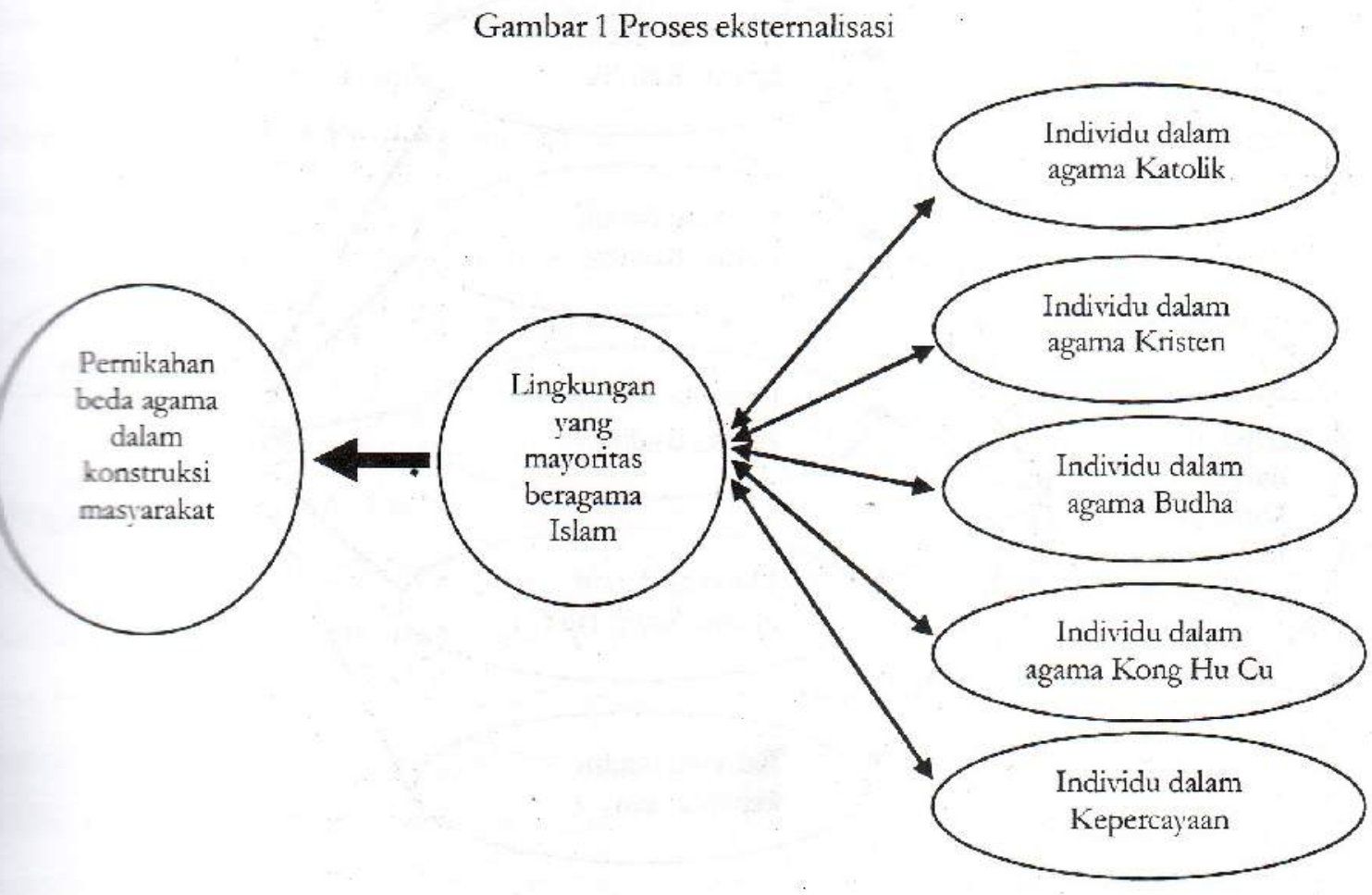

Pada sisi lain, manusia sebagai individu dituntut untuk mengkonstruksi dirinya sendiri secara terus menerus, guna mencapai suatu kemandirian melalui kesadarannya dalam menyerap senlitas yang ada di tengah-tengah kehidupan masyarakat sekitar. Dalam kemandiriannya inthh manusia sebagai individu, melakukan internalisasi terhadap apa yang dialaminya saat proses eterternalisasi, dan menyerapnya ke dalam kesadaran individunya sebagai sesuatu yang lhurss dipelihara dalam upaya mempertahankan dan memperkuat solidaritas di antara mereka. Konstruksi sosial pernikahan beda agama di kalangan muslim Tionghoa Probolinggo dengan demikian merupakan hasil proses internalisasi dari individu etnis ini terhadap realitas 
ljthad, Jurnal Wacana Hukum Islam dan Kemanusiaan, Vol. 11, №. 2, Desember 2011: 127-143

objektif yang ada di tengah-tengah kehidupan masyarakat yang mayoritas beragama Islam. Hasil dari proses tersebut berupa kesadaran individu dalam melaksanakan pernikahan beda agama sebagai sebuah pengamalan dari agama yang diyakininya.

Proses internalisasi pernikahan beda agama yang merupakan tahapan dari konstruksi sosial yang mereka lakukan dapat diilustrasikan sebagi berikut:

\section{Gambar 2 Proses internalisasi}

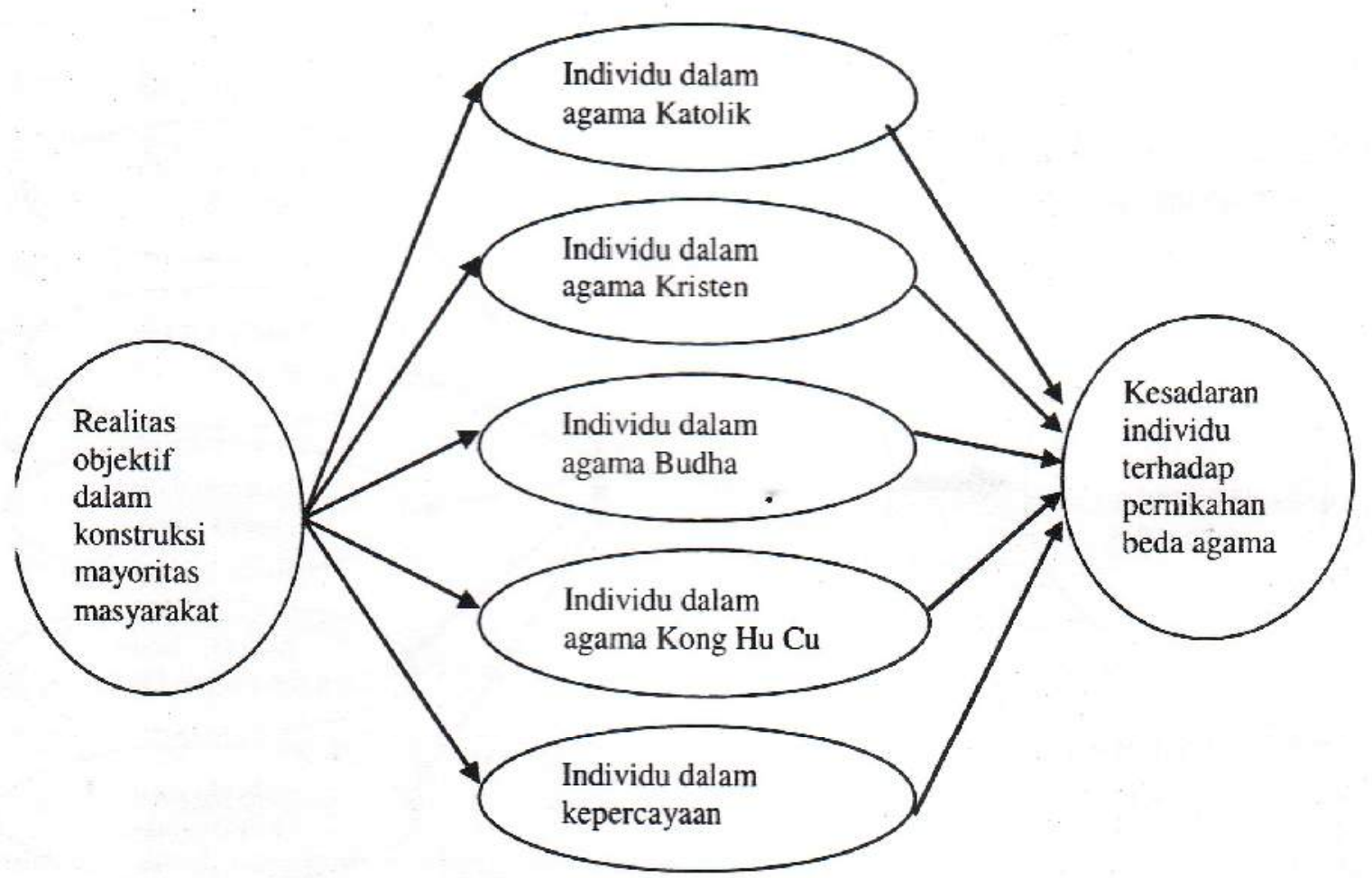

Objektivasi adalah hasil akhir dari proses eksternalisasi dan internalisasi yang dilakukan oleh individu di tengah-tengah kehidupan masyarakat. Hasil akhir tersebut dalam tahapan konstruksi sosial, menjadi suatu realitas tersendiri yang secara objektif berada di luar individu dan masyarakat pembentuknya yang sejak awal mengantar dan terlibat langsung dalam proses pembentukannya. Pada saat realitas tersebut telah berdiri sebagai sebuah realitas objektif, individu dan masyarakat mulai mengambil jarak. Sebagai sebuah realitas, segalanya menjadi otonom dan berjalan menurut garis lingkarnya sendiri. Dalam kondisi seperti ini, realitas objektif tersebut memaksa individu dan masyarakat untuk mengikuti alur dari sistem arus 
garis lingkar yang dibentuknya di tengah-tengah kehidupan masyarakat yang mengitarinya. Itulah gambaran pernikahan beda agama di kalangan muslim Tionghoa Probolinggo.

Di dalam perspektif Berger pernikahan di kalangan muslim Tionghoa Probolinggo dapat dibaca sebagai sebuah realitas objektif yang berdiri sendiri dan terpisah dari pembentuknya. Pembentuk realitas tersebut adalah individu dan masyarakat pada saat etesternalisasi dan internalisasi berlangsung. Sebagai suatu realitas objektif yang terpisah dari pembentuknya, pernikahan beda agama mengambil bentuknya sendiri di tengah-tengah kehidupan. Oleh karena itu, dia berjalan dalam sistemnya sendiri dan bahkan dia memaksa individu dan masyarakat untuk mengakui dan mengikuti arah, dinamika dan sistematikanya. Meskipun pernikahan beda agama adalah realitas yang ada di tengah-tengah kehidupan dan berjalan di atas garis lingkarnya sendiri, keberadaannya sama dengan institusi kemasyarakatan yang lain seperti agama, budaya, norma yang berlaku dan lain-lainnya. Pernikahan beda agama ini pun akhirnya menjadi bagian tak terpisahkan dan menjadi representasi dari keberadaan masyarakat tersebut.

Sebagai sebuah realitas objektif yang terpisah dengan individu dan masyarakat sebagai pembentuknya, pernikahan beda agama di kalangan etnis 'Tionghoa Probolinggo ini, cenderung mengabaikan apa yang bersifat bigh tradition dari agama yang dipeluknya. Keharaman pernikahan beda agama yang difatwakan oleh Majelis Ulama Indonesia (MUI) dan beberapa tokoh agama lainnya termasuk juga kebiasaan mereka memasukkan pendidikan putra-putrinya ke lembaga pendidikan yang tidak berbasis Islam seperti SD, SMP dan SMA/ SMK Katolik dan lain sebagainya. Sedikit sekali mereka yang memperhatikan keyakinan agama Islam bagi putra-putrinya dan pada umumnya mereka memberi kebebasan kepada putra-putrinya itu untuk menyakini agama yang disenanginya.

$\mathrm{Hal}$ tersebut merupakan representasi dari masyarakat yang mengitarinya, yang ditandai oleh adanya penerimaan mereka dalam menghadiri pelaksanaan pernikahan beda agama. Tidak sebatas itu saja, pemerintah daerah kabupaten Probolinggo ikut berpartisipasi memberikan fasilitas Islamic Centre sebagai tempat resepsinya. Penerimaan ini menjadi bukti bahwea objektivasi pernikahan beda agama, telah berada dalam bentuknya tersendiri dalam otoritas dan sistemnya sendiri di luar individu dan masyarakat sebagai pembentuknya.

Konstruksi objektivasi pernikahan beda agama di atas dapat diilustrasikan sebagai berikut; 
Gambar 3 Konstruksi objektivasi

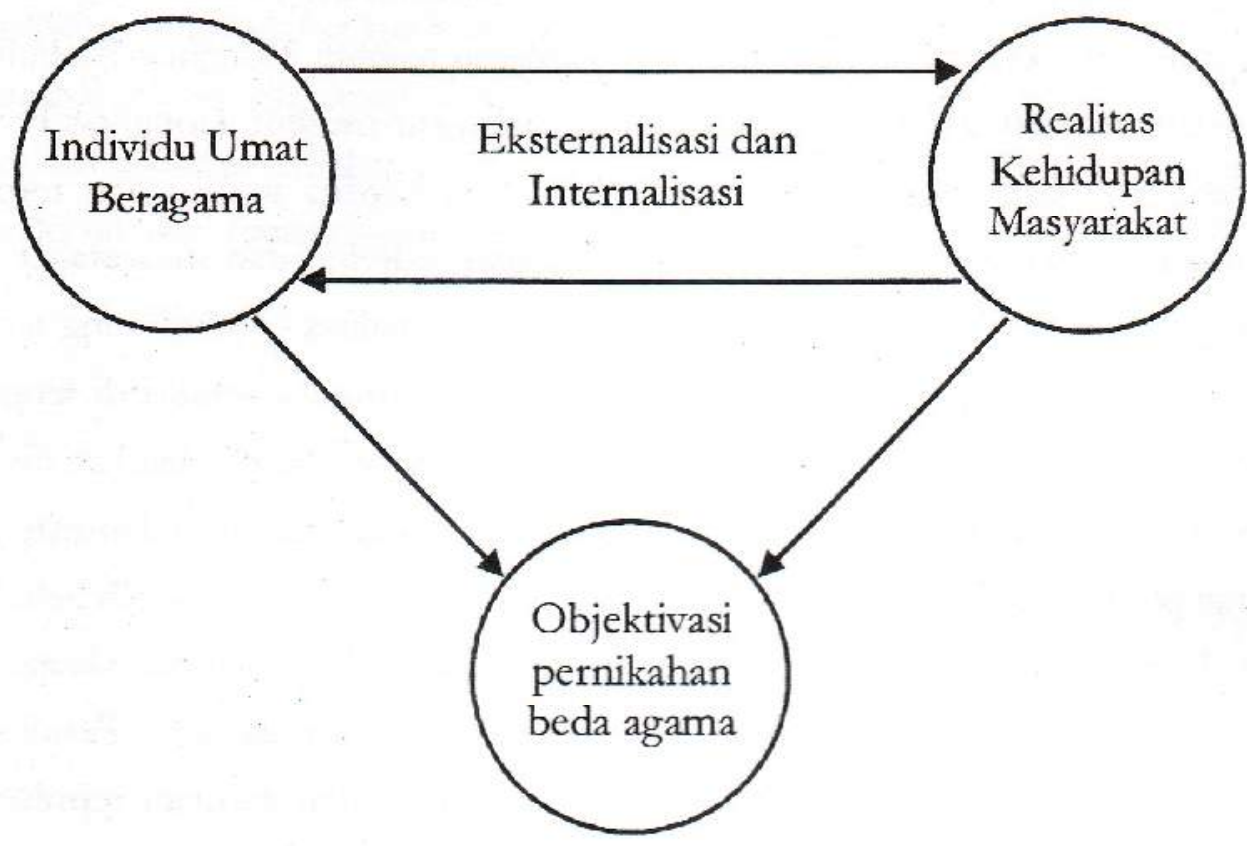

Demikian konstruksi sosial pernikahan beda agama di Probolinggo terbentuk di tengahtengah kehidupan umat bergama yang mayoritas beragama Islam melalui proses eksternatisasi, internalisasi dan objektivasi dari teori Peter L. Berger.

\section{Pernikahan beda agama dalam pendekatan konsep ideal Islam}

Dalam prespektif teori Berger, konstruksi pernikahan beda agama sebagai fenomena sosial di kalan an muslim Tionghoa Probolinggo telah terbangun, dan hal ini terjadi tentu tidak secara kebetulan. Hal tersebut terjadi karena masyarakat Probolinggo yang didominasi oleh etnis Madura sama dengan daerah-daerah lainnya di kawasan tapal kuda, berkarakter keras, kuat mempertahankan kehormatan, dan emosinya mudah terbakar khususnya jika keyakinan agamanya terganggu.

Namun demikian, ketika Liem Giok Sing (H. Moh. Alimakki), ketua PITI Probolinggo, menikahkan putrinya, Dewi Yuliana yang tidak mengikuti keyakinan ayah dan ibunya, karena anaknya beragama Katolik menikah dengan Kwiek Fung Fung, yang beragama Kong Hu $\mathrm{Cu}$, dan pernikahannya dilaksanakan menurut agama Budha, masyarakat sekitar tidak mempermasalahkannya. 
Konstruksi sosial pernikahan beda agama di kalangan Muslim Tionghoa... (M. Hasyim Syamhudi)

dari al-Mäidah dan tentu saja tidak logis sesuatu yang datang terlebih dahulu membatalkan hukum sesuatu yang belum datang atau yang datang sesudahnya (Shibab, 2005: 474). Apalagi, masih menurut M. Quraish Shihab, banyak riwayat yang mengatakan bahwa sebagian sahabat. Nabi saw., dan tabi'in ada yang menikah dengan abl al-kitäb. Khalifah Usman bin 'Affan misalnya, menikah dengan wanita Kristen, walaupun kemudian isterinya memeluk agama Islam, Thalhah bin Zubair, dua orang sahabat nabi saw. terkemuka juga menikah dengan wanita Yahudi.

Tawaran ulama ușul al-figh tentang berputarnya ketentuan hukum bersama 'illab-nya di atas perlu dipertimbangkan demi keberlangsungan misi kenabian, rạ̣matan li al-älamin. Senada dengan ulama $u s \bar{u} l$ al-fiqh, Alwi Shihab, ketika mengomentari larangan al-Qur'an untuk menjadikan orang Yahudi dan Nastani sebagai sekutu umat Islam seperti di dalam al-Qur'an surat al-Má'idah 5: 51, dipahami sebagai sebuah larangan yang pada dasarnya merujuk kepada persekutuan politis dalam satu peristiwa perang. Ironis menurutnya, jika hal tersebut menjadi normatif bagi kalangan muslim. Padahal bagitu banyak perintah al-Qur'an yang menganjurkan untuk membangun persahabatan dan kerjasama antara muslim dengan abl al-kitäb (Shihab, 2001: 326). Selengkapnya terjemah surat al-Má'idah 5: 51-tersebut adalah:

"Hai orang-orang yang beriman, janganlah kamu mengambil orang-orang Yahudi dan Nasrani menjadi pemimpin-pemimpin(mu), sebagian mereka adalah pemimpin bagi sebagian yang lain. Barang siapa di antara kamu mengambil mereka menjadi pemimpin, maka sesungguhnya orang itu termasuk golongan mereka. Sesungguhnya Allah tidak memberi petunjuk kepada orang-orang yang zalim."

Relasi antar penganut agama dalam perspektif ini menjadi tidak terbatas dan bahkan heloar melampaui batas-batas agama, budaya dan etnis. Paling tidak dengan diterimanya isu humanisme, HAM (hak asasi manusia) dan keadilan gender di tingkat global, menjadikan perbedaan keyakinan agama bukanlah suatu hambatan untuk menciptakan suatu rumah tangga bedh agama melalui proses pernikahan. Bahkan dengan kemajuan itu setiap penganut agama sermakin mengetahui praktik-praktik ritual yang dilakukan oleh masing-masing penganut agama melalui bermacam-macam media baik cetak maupun elektronik.

Pada saat pelaksanaan ibadah haji oleh umat Islam yang berlangsung di Makkah misalnya, Hhasusnya ketika tawaf dan wukuf di Arafah dengan penuh khusyuk dan tawadhuk, pada 
Demikian juga, Tjan Tong Hin, (H. Edi Saputra), wakil ketua PITI Probolinggo, yang membiarkan anaknya, Gunawan Atmojo yang beragama Islam memilih isteri berkewarganegaraan China, Deng Ling yang beragama Kristen, dan pernikahannya dilaksanakan secara Kristen, masyarakat justeru ikut memeriahkan dan bahkan keterlibatan pemerintah daerah yang memberikan banyak kemudahan untuk menempati gedung Islamic Confre menjadikan suasana pernikahan semakin meriah.

Sebagai fenomena sosiologis, pernikahan beda agama di kalangan muslim Tionghoa Probolinggo akhirnya diterima sebagai sebuah realitas objektif yang merupakan konstruksi dan hasil eksternalisasi, internalisasi dan objektivasi individu dan masyarakat dalam sebuah kehidupan umat beragama. Sebagai sebuah realitas objektif, masih banyak pernikahan serupa yang tidak mungkin dijelaskan dalam tulisan ini, seperti yang terjadi dalam keluarga Poo Gwan Tek (H. Sutikno), Tan Tjing Gan (H. Edi Santuso), Ho Bing Kiat (H. Abd. Ghani Zakaria), termasuk ketua PITI Jawa Timur, Wu Qiong Zhi yang sekarang dikenal dengan mama Edwin Suryalaksana.

Kehadiran pernikahan beda agama merupakan hasil dari konstruksi sosial masyarakat yung berseberangan dengan kepercayaan dan keyakinan agama di lingkungannya. Namun demikian, sebagai sebuah fenomena sosiologis yang berjalan di atas proses eksternalisasi, incernaficasi, dan objektivasi justeru menjadi suatu realitas objektif yang tidak dapat dipungkiri keberadaannya.

Idealnya pernikahan memang harus dilakukan antara pasangan yang seiring dan sebangun dalam berbagai hal seperti dalam hal bagus rupa, tercukupinya kebutuhan ekonomi, nasab serta kepercayaan dan keyakinan agamanya seperti yang disabdakan Rasulullah saw., sebagai bernkut (Al-Bukhari: t.th.: 342):

"Bercerita kepada kami Musaddad, bercerita kepada kami Yahya dari 'Abdillah, dia berkata, bercerita kepadaku Sa'id bin Abi Sa'id dari ayahnya, dari Abi Hurairah ta., dari Nabi Muhammad saw: perempuan dinikahi karena empat hal yaitu, karena hartanya, hebangsawanannya, kecantikannya dan karena agamanya, tetapi pilihlah yang beragama agar selamatlah dirimu" (Hr. Bukhari).

Namun demikian, apa yang bersifat ideal dari pernikahan tersebut, dirasa sulit dilaksanakan lich umatnya karena berbagai kondisi yang secara sosiologis berbeda antara calon suami dun calon isteri, di samping karena perintah pernikahan yang bersifat sunnah pada hukum 
Ijtihad, Jurnal Wacana Hukum Islam dan Kemanusiaan, Vol. 11, No. 2, Desember 2011: 127-143

asalnya. Bahkan Rasulullah Muhammad saw. sendiri juga tidak berada dalam tataran konsep ideal tersebut. Sebab, seperti diketahui bahwa isteri Rasulullah yang pertama adalah Khadijah yang usianya lebih tua 15 tahun, sementara isteri kedua adalah 'Aisyah yang masih berusia sembilan tahun saat dinikahi Rasulullah dan Maria Qibtiyah yang menurut Said Aqil Shiradj, tidak seagama karena mereka dari kalangan ahli al-Kitab yaitu Nashara (Shiradj, 2007: 22). Senada dengan Said Aqil Shiradj, Karen Armstrong juga menginformasikan tentang Kristennya Maria Qibtiyah saat dinikahi Rasulullah saw., dan mensejajarkannya dengan Nabi Ibrahim yang menikahi seorang hamba sahayanya, yakni Hajar (Armstrong, 2006: 342).

Sungguhpun demikian, beberapa perbedaan dalam pernikahan tersebut tidak menghalangi terkondisinya relasi yang harmonis dari para anggota keluarga rumah tangga Rasulullah saw. Dengan demikian, konsep ideal dari pernikahan tidak harus dipahami sebagai konsep moral yang bersifat qath'i (paten), tetapi diletakkannya di atas pemahaman yang secara soiologis sejalan dengan perkembangan dan perubahan seperti yang digariskan para ulama usüul al-figh, الحلكم يد ور مع العلة وجودا وعدما (hukum itu berputar bersama 'illah-nya dalam mewujudkan dan meniadakan hukum) (Fathurrahman, 1996: 550).

Dengan demikian, dapat dipahami bahwa pada saat konsep ideal pernikahan dideklarasikan oleh Rasulullah saw., kondisi sosiologis umat Islam masih berada dalam proses pembinaan dan pembentengan dari pengaruh pemikiran dan budaya agama lain di samping untuk lebih memperkokoh keberlangsungan komunitas umat Islam. Pada saat itu diskursus dä al-kuj är (daerah tidak aman) dan däral-Istam (daerah aman) menjadi sangat kental, termasuk adanya garis batas antara sebutan Arab dan 'ajam. Kondisi sosiologis yang demikian seolah ikut memberikan arah bagi konsep ideal pernikahan di atas.

Demikian juga konsep ideal pernikahan, yang terkait dengan pelarangan pernikahan beda agama, seperti yang tercantum dalam surat al-Baqarah 2: 221, sebaiknya didekatkan kepada kondisi sosiologis pada saat turunnya ayat tersebut karena ternyata di tempat lain, yaitu di dalam surat al-Mä'idah 5: 5, al-Quran memberikan ijin untuk mengawini perempuan ablalkitäb. Menghadapi dua ketentuan hukum yang berbeda ini, sebagian ulama berpendapat bahwa kebolehan nikah beda agama dalam surat al-Ma'idah 5: 5 itu, telah dinasakh atau dihapus secara hukum oleh surat al-Baqarah: 221 di atas. Namun menurut M. Quraish Shihab, pendapat ini sangat sulit untuk diterima, karena ayat al-Baqarah lebih dahulu turun 
Konstruksi sosial pernikahan beda agama di kalangan Muslim Tionghoa... (M. Hasyim Syamhudi)

dari al-Mäidah dan tentu saja tidak logis sesuatu yang datang terlebih dahulu membatalkan hukum sesuatu yang belum datang atau yang datang sesudahnya (Shibab, 2005: 474). Apalagi, masih menurut M. Quraish Shihab, banyak riwayat yang mengatakan bahwa sebagian sahabat Nabi saw., dan tabi'in ada yang menikah dengan abl al-kitäb. Khalifah Usman bin 'Affan misalnya, menikah dengan wanita Kristen, walaupun kemudian isterinya memeluk agama Islam, Thalhah bin Zubair, dua orang sahabat nabi saw. terkemuka juga menikah dengan wanita Yahudi.

Tawaran ulama ușül al-figh tentang berputarnya ketentuan hukum bersama 'illab-nya di ams perlu dipertimbangkan demi keberlangsungan misi kenabian, rạ̣matan li al-álamin. Senada dengan ulama ușül al-fiqh, Alwi Shihab, ketika mengomentari larangan al-Qur'an untuk menjadikan orang Yahudi dan Nasrani sebagai sekutu umat Islam seperti di dalam al-Qur'an surat al-Ma'idah 5: 51, dipahami sebagai sebuah larangan yang pada dasarnya merujuk kepada persekutuan politis dalam satu peristiwa perang. Ironis menurutnya, jika hal tersebut menjadi normatif bagi kalangan muslim. Padahal bagitu banyak perintah al-Qur'an yang menganjurkan untuk membangun persahabatan dan kerjasama antara muslim dengan abl al-kitäb (Shihab, 2001: 326). Selengkapnya terjemah surat al-Mä'idah 5: 51-tersebut adalah:

"Hai orang-orang yang beriman, janganlah kamu mengambil orang-orang Yahudi dan Nasrani menjadi pemimpin-pemimpin(mu), sebagian mereka adalah pemimpin bagi sebagian yang lain. Barang siapa di antara kamu mengambil mereka menjadi pemimpin, maka sesungguhnya orang itu termasuk golongan mereka. Sesungguhnya Allah tidak memberi petunjuk kepada orang-orang yang zalim."

Relasi antar penganut agama dalam perspektif ini menjadi tidak terbatas dan bahkan keluar melampaui batas-batas agama, budaya dan etnis. Paling tidak dengan diterimanya isu humanisme, HAM (hak asasi manusia) dan keadilan gender di tingkat global, menjadikan perbedaan keyakinan agama bukanlah suatu hambatan untuk menciptakan suatu rumah tangga bedh agama melalui proses pernikahan. Bahkan dengan kemajuan itu setiap penganut agama semalin mengetahui praktik-praktik ritual yang dilakukan oleh masing-masing penganut agama melalui bermacam-macam media baik cetak maupun elektronik.

Pada saat pelaksanaan ibadah haji oleh umat Islam yang berlangsung di Makkah misalnya, khususnya ketika tawaf dan wukuf di Arafah dengan penuh khusyuk dan tawadhuk, pada 
saat itu pula, semua penganut agama di dunia menyaksikan semarak kebersamaan umat Islam menemukan kedamaian dan kchangatan bersama Allah swt. Begitu pula pada saat umat Kristiani melaksanakan kebaktian di Vatikan Roma ketika hari Natal tiba, pada saat itu pula, semua penganut agama di dunia menyaksikan semarak kebersamaan umat Kristiani menemukan kedamaian dan kehangacan dalam kasih Yesus. Demikian juga pada saat para biksu dan umat Budha berkumpul di Borobudur, melakukan kebaktian Waisak, pada saat itu pula, semua penganut agama di dunia menyaksikan suasana kekhusyukan, dan mereka larut dalam belaian Sang Pencipta.

Peristiwa-peristiwa sakral tersebut, berlangsung secara terus menerus pada setiap tahun, schingga disadari atau tidak, penganut agama menjadi tidak asing terhadap perbedaanperbedaan dalam praktik keagamaan. Kondisi ini akan membentuk karakter seriap pemeluk agama, mengakui bahwa ternyata di luar kebenatan yang diyakini, ada kebenaran lain yang diyakini oleh orang lain di sekitarnya. Relasi antar penganut agama, dengan tanpa harus mencampur-adukkan kebenaran suatu agama, akan melahirkan sikap harmoni, empati, saling menghargai dan saling menghormati antara satu dengan yang lain. Bahkan, saling mencintai untuk kemudian ditingkatkan relasinya dalam sebuah bangunan rumah tangga melalui proses pernikahan. Dari perspektif normatif memang ada hambatan, namun apapun yang mereka lakukan dari membangun rumah tangga melalui pernikahan, sebetulnya tidak lebih dari melanggengkan rasa cinta yang secara fitrah adalah suci karena hal tersebut pemberian Tuhan Sang Pc, cipta. Oleh karena itu dapat dipastikan bahwa semua agama di dunia, tidak ada yang mengajarkan kekerasan dalam kaitannya dengan relasi antar penganut agama. Hal ini tidak saja, karena secara sosiologis, manusia saling membutuhkan antara satu dengan yang lain dalam kerangka relasi, tetapi lebih dari itu karena semua agama mengajarkan cinta, keharmonisan dan kerukunan.

Dengan demikian, pernikahan beda agama yang merupakan fenomena sosiologis di tengah-tengah rentannya konfik barizontal yang bernuansa agama seperti di Indonesia, akan menjadi wahana terkonstruksinya kesepahaman antar masing-masing penganut agama. Bermula dari ikatan kasih dan sayang antara suami-isteri, menuju kerukunan dan kedamaian antara penganut agama dari keluarga pihak suami dan isteti, pada akhirnya, akan terbangun sebuah peacebrilding bahkan pearekeeping sekaligus di negeri ini. Hal ini sangat memungkinkan 
lurena semuanya telah bersaudara sebagai saudara besan, menantu, mertua dan saudara ipar rang skan mengedepankan ikatan emosional persaudaraan.

Sebenamya pernikahan beda agama di Indonesia, telah berlangsung sejak lama tanpa ulary suatu hambatan yang berarti. Konon Prabu Kertawijaya sebagai raja Majapahit yang bengama Hindu, telah mempersunting putri Champa, bibi Sunan Ampel yang beragama Ihlam, bernama Darawati. Dalam hal ini, Agus Sunyoto berpandangan bahwa Prabu Kertawijaya di samping mengambil permaisuri Darawati dari Champa, dia juga mempetisterikan gadis Cina lain, Retno Subanci binti Encik Ban Chun yang beragama Islam Aan Gresik (Sunyoto, 2004: 26). Bahkan tidak hanya bibi Sunan Ampel yang melakukan Lusin beda agama, Sunan Shaikh Maulana Ishaq seperti yang dituturkan Baidlawi Syamsuri 19995: 41) di dalam bukunya Kisab Wall Songo menyebutkan bahwa dia melangsungkan pernikahan dengan putri Blambangan yang bernama Sekar Dadu. Apa yang dilakukan bibi Sunan Ampel yang kemudian diikuti oleh Shaikh Maulana Ishaq mengindikasikan bahwa pernikahan beda agama telah lama berlangsung. Sekar Dadu adalah putri Prabu Minak Sembuyu, raja Blambangan yang juga masih keturunanan raja Hayam Wuruk dari kerajaan 3ajapahic.

Bahkan diduga pernikahan beda agama ini telah terjadi jauh sebelum para walisongo mengembangkan dakwahnya di pulau Jawa, yakni pada saat Raden Wijaya, raja pertama Mijapahit, memberangus tentara Mongol yang akan mengadakan balas dendam terhadap peristiwa potong telinga terhadap utusan Khubilai Khan yang bernama Meng K'i oleh Prabu Kettanegara di Singasari (1251-1292) (al-Qurtuby, 2003; 1979).

Konsesi politik yang berisi penyerahan separuh kekuasaan kepada tentara Mongol oleh Singosari tidak ditepati oleh Jayakatwang, pengganti Prabu Kertanegara. R. Wijaya justeru memberangus tentara Mongol tersebut sehingga mereka berserakan ke mana-mana, di antaranya ada yang pulang ke China, namun ada juga yang bersembunyi dan berasimilasi dengan penduduk setempat di Madura dan Kalimantan Barat.

Dengan demikian tidak heran jika catatan sektetaris Cheng Ho, Ma Huan saat dia datang ke Jawa pada tahun 1433 M., telah menemukan tiga kelompok pemukim utama, yaitu, pertama muslim dari Arab dan Persi, kedua muslim China dan ketiga pribumi yang masih kafir dengan cara hidup kotor dan memuja roh (Suyoto, 2008: 1). 
Kelompok China yang beragama Islam ini adalab keturunan tentara Mongol yang diberangus oleh Raden Wijaya (al-Qurthubi, 2003: 79). Scjak saat itu tidak diragukan lagi adanya nikah beda agama, betada di bawah kerajaan Singasari dan Majapahit yang masih memeluk agama Hindu, dan masih memuja roh, sementara tentara Mongol yang datang untuk balas dendam itu adalah etnis Mongol yang sebagiannya telah beragama Islam (Hamka, 1981: 43).

Pemahaman akan konsep ideal (al-Baqarah 2: 221 dan hadis Bukhari) di atas, menjadi sangat dibutuhkan di tengah-tengah kehidupan, yang secara sosiologis dipadati oleh tuntutan hidup harmoni, tuntutan untuk saling menghargai hak asasi manusia (HMM), tuntutan untuk saling menghormati dan menghargai perbedaan, tuntutan keadilan, serta tuntutan untuk hidup rukun dan damai dalam sebuah kolong dunia yang satu seperti sekarang ini. Dengan kata lain, agar teks suci keagamaan, al-Qur'an maupun al-Hadis yang tidak bisa berbicara itu terkesan mati sebagai musium warisan abad ke VII, maka untuk menyegarkan dan menghidupkannya diperlukan suatu pemahaman yang dapat menggambarkan konsep rabmatan if al: älawion dari agama Islam.

Pemahaman yang dimaksud adalah mempertimbangkan kondisi sosial pada saat kondisi ideal scbuah pernikahan itu disabdakan oleh Rasulullah atau difirmankan oleh Allah swt, dan mengklarifikasikannya kepada kondisi sosial sekarang dan menempatkannya di atas berbagai warisan pemikiran intelektual terdahulu.

Olet karenanya larangan nikah dengan pria dan wanita musyrik seperti yang tercantum dalam surat al-Baqarah 2: 221, misalnya dapat diletakkan di atas penafsiran Qatadah yang mengatakan bahwa larangan nikah dengan wanita musyrik adalah dikarenakan mereka tidak memiliki kitab suci.

"Dari 'Ammar bercerita kepadaku, bercerita kepadaku putra Abi Ja"far yang bersumber dari ayahnya dan semula dari sahabat Qatadah tentang firman Allah yang berbunyi,

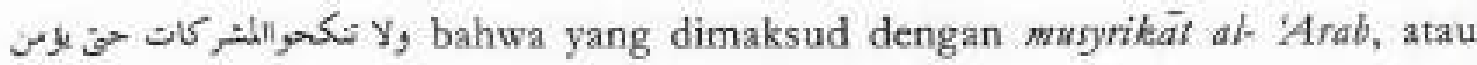
perempuan-perempuan musyrik arab adalah karena mereka tidak memiliki kitab suci yang dibacanya" (al-Thabari: t.th., 389).

Senada dengan Qatadah adalah, Moh. Abduh dan Rashid Rida, yang mengatakan bahwa yang dimaksud musbrikin, mssbrikät di dalam surat al-Baqarah: 221 adalah terbatas hanya 
pada zaman nabi, karena ada keterkaitannya antara perkawinan musbrikēat dan mushrikein dengan budak, sementara sekarang persoalan budak sudah tidak ada dan karenanya mushrikin, musbrikä yang dimaksudkan juga menjadi tidak ada. Menurut kelompok ini pula, ketidakbolehan pernikahan beda agama seperti yang tercantum di dalam surat al-Mumtahanah: 10, juga dipahami sebagai larangan yang secara sosiologis umat Islam pada saat itu berada dalam kontek peperangan, dan hal tersebut telah dinasakb oleh surat al-Mà'idah 5: 5.

\section{Penutup}

Pernikahan beda agama sebagai fenomena sosial, khususnya yang banyak terjadi di kalangan muslim Tionghoa Probolinggo, menjadi sesuatu yang menarik. Tidak saja karena kehadirannya yang mendapat respon positif dari lingkungan masyarakat sekitar, tetapi juga karena berseberangan dengan mainstream pernikahan seagama yang dianut oleh kebanyakan umat beragama.

Pernikahan beda agama di kalangan muslim Tionghoa Probolinggo adalah fenomena sosial sebagai hasil dari kontruksi sosial umat beragama secara keseluruhan. Mereka berintegrasi dengan lingkungan masyarakat sekitar melalui proses sosial yang secara bertahap bergerak dari eksternalisasi, objektivasi dan internalisasi.

Pendekatan Qatadah yang sejalan dengan Moh. Abduh dan Rasyid Ridla dalam memahami pernikahan beda agama menurut konsep ideal Islam adalah jalan tengah untuk menyelesaikan problem larangan dan kebolehan pernikahan beda agama yang ada, khususnya ketika dilkaitkan dengan pernikahan beda agama sebagai sebuah realitas dalam konstruksi sosial.

\section{Daftar pustaka}

A1-Bukhari, Abi Abdillah Muhammad bin Ismail. Matn al-Bukbāri. Mesir: Maktabah alNașiriyah, t.th.

Diepag RI. Al-Qur'an dan Terjemabannya. 1984/1985.

41-Qurtuby, Sumanto. Arus China-Islam-Jawa, Bongkar Sejarab atas Peranan Tionghoa dalam Perjebaran Islam di Nusantara abad XV dan XVI. Jakarta: Inspeal Ahimsa Karya Press, 2003.

ALSuruti, Jalal al-Din, 'Abdu al-Rahman bin Abi Bakar. Al-jämi' al-Saghìr $\bar{f} i$ Abädìth al-Bashir al-Nadhir: Asia: Al-Shirkah Nür, t.th. 
ljtihad, Jurnal Wacana Hukum Islam dan Kemanusiaan, Vol. 11, No. 2, Desember 2011: 127-143

Al-Thabari, 'Ali Jakfar Muhammad bin Jarir. Tafsìr al-Tabari al-Musammā Jämi' al-Bayān fi Ta'wil al-Qur'an, Juz II. Beirut: Ḍar al-Kutub al-Alāmiah. $t$ th.

Anggoro, Dony. Pernikahan Beda Agama, Kesaksian, Argumen Keagamaan dan Analisis Kebijakan. Ahmad Baso dan Ahmad Nurcholish (ed.). Jakarta: Komnas HAM \& ICRP, 2005.

Armstrong, Karen. Muhammad Sang Nabi: Sebuab Biografi Kritis. Surabaya: Risalah Gusti, 2006.

Berger, Peter L. Langit Suci: Agama Sebagai Realitas Sosial. Jakarta: LP3ES, 1991.

Binti Shati'. Nisä' al-Nabì 'Alaih al-Ṣalăh wa al-Saläm. Terjemah 'Abdullah Zaki Alkaf. Bandung: Pustaka Hidayah, 2001.

Bungin, Burhan. Analisis data Penelitian Kualitatif. Jakarta: PT. Raja Grafindo Persada, 2007.

De Graaf, Hj. dan Pigeaud, Th. Kerajaan Islam Pertama di Jawa: Tinjauan Sejarah Politik Abad XV Dan XVT. Yogyakarta: Pustaka Pelajar, 2001.

- dkk. China Muslim di Jawa Abad XV dan XVI. Terjemah Alfajri, Yogyakarta: PT. Tiara Wacana, 2004.

Geertz, Clifford. Abangan, Santri, Priyayi dalam Masyarakat Jawa. Jakarta: Pustaka Jaya, 1983.

Goode, Willdiam J. Sosiologi Kelnarga. Terjemah Laila Hanom Hasyim. Jakarta: Bina Aksara, 1985.

Gunaryo, Achmad, "Konflik dan Pendekatan Terhadapnya” dalam M. Mukhsin Jamil (ed.). Mengelola Konflik Membangun Damai. Semarang: IAIN Walisongo, 2007.

Hamka. Tasanuf, Perkembangan dan Pemurniannya. Jakarta: PT. Pustaka Panji Masyarakat, 1984. Moleong, Lexy, J. Metodologi Penelitian Kualitatif. Bandung: PT.Remaja Rosdakarya, 2000.

Mulia, Misdah. Muslimab Reformis. Bandung: Mizan, 2005.

Partanto, Pius A. dan Al Barry, M. Dahlan. Kamus Ilmiyab Populer. Surabaya: Arkola, 1994.

Ritzer, George dan Goodman, Douglas J. Teori Sosiologi Modern. Jakarta: Kencana, 2007.

Romadhani, Ali, "Menemukan Jejak China dan Hindu dalam Islam Jawa", Jurnal al-Istiqro". Vol. 7, No. I (2008).

Sabiq, Sayid. Fikib Sunah. Terj. Moh. Thalib. Bandung: PT.Al-Maarif, 1981.

Scharf, Betty R. Sosiologi Agama. Terj. Machnun Husen. Jakarta: Kencana, 2004.

Setiawan, Candra, "Agama Kong $\mathrm{Hu} \mathrm{Cu}$ di Indonesia" dalam Passing Over, Melintas Batas Agama. Jakarta: PT.Gramedia Pustaka Utama, 2001.

Shihab, Alwi, "Hubungan Islam dan Kristen Memasuki Abad 21" dalam Passing Over, Melintas Batas Agama. Jakarta: PT.Gramedia Pustaka Utama, 2001.

Shihab, M. Quraish. Tafsir al-Misbah. Tangerang: Lentera Hati, 2005. 
Konstruksi sosial pernikahan beda agama di kalangan Muslim Tionghoa... (M. Hasyim Syamhudi)

Siradj, Said Aqil, "Islam Wasathan sebagai Identitas Islam Indonesia", Jurnal Taswir AlAflear, No. 22 (2007).

Sunyoto, Agus. Sunan Ampel Raja Surabaya. Surabaya: Diantama, 2004.

Suryadinata, Leo. Negara dan Etbnis Tionghoa, Kasus Indonesia. Jakarta: LP3ES, 2002.

Suryadinata, Leo. Pemikiran Politik Etnis Tionghoa 1900-2002. Jakarta: LP3ES, 2005.

Syam, Nur. Islam Pesisir. Jogjakarta: LKiS, 2005.

Syamsuri, Baidlowi. Kisab Walisongo, Penyebaran Agama Islam di Tanah Jawa. Surabaya: Apollo, 1995.

Yaqub, Ali Mustafa. Nikah Beda Agama dalam Perspektif al-Qur'an \& Hadis. Jakarta: Pustaka Darus-Sunah, 2005.

Zuhri, Saifuddin. Sejarah Kebangkitan Islam dan Perkembangannya di Indonesia. Bandung: PT. AlMaarif, 1979. 